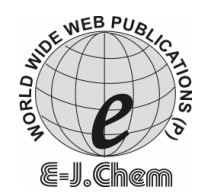

http://www.e-journals.net
ISSN: 0973-4945; CODEN ECJHAO

E-Journal of Chemistry

2010, 7(4), 1200-1205

\title{
Synthesis of Zeolite from Fly Ash and Removal of Heavy Metal Ions from Newly Synthesized Zeolite
}

\author{
PARAG SOLANKI*, VIKAL GUPTA and RUCHI KULSHRESTHA \\ Department of Chemistry, \\ Jai Naraiyan Vyas University, Jodhpur-342001, India. \\ parag_solanki84@yahoo.co.in
}

Received 11 November 2009; Revised 8 January 2010; Accepted 5 March 2010

\begin{abstract}
Coal fly ash was used to synthesize X-type zeolite by alkali fusion followed by hydrothermal treatment. Characteristics of the various Fly ash samples were carried out. Coal proximate analysis was done. Batch experiment was carried out for the adsorption of some heavy metal ions on to synthesized Zeolite. The cost of synthesized zeolite was estimated to be almost one-fifth of that of commercial 13X zeolite available in the market.
\end{abstract}

Keywords: Zeolite, Geopolymer, Fly ash, Hydro thermal treatment, Proximate analysis, XRF analysis.

\section{Introduction}

The amount of coal fly ash generated by coal-based thermal power plants has been increasing at an alarming rate throughout the world. The disposal of such a huge quantity of ash has become a pressing issue. Several approaches have been made for proper utilization of fly ash, either to reduce the cost of disposal or to minimize the environmental impact. One of the approaches is the conversion of fly ash to zeolites, which have wide applications in ion exchange, as molecular sieves, catalysts and adsorbents ${ }^{1}$. The present study is concerned with the synthesis of zeolite from coal fly ash and its Uses in Effluent treatment.

The term "geopolymer" was first used by Davidovits ${ }^{2,3}$ to describe a family of mineral binders closely related to artificial zeolites. These structures consist of a polymeric Si-O-Al framework, similar to that found in zeolites. Geopolymers are sometimes also referred to as alkali-activated aluminosilicate binders ${ }^{5,6}$.

Heavy metals in waste water have emerged as the focus of environmental remedial efforts because of their toxicity and threat to human beings. Due to rapid growth of industrialization and urbanization with new technological advancement, the existing water resources are contaminated by discharging waste water containing organics, colour, heavy metals, etc. Hence, removal of toxic and heavy metal contaminates from wastewater is one 
of the most important environmental and economic issues. Many models of adsorption for cations and anions on surface have been developed considering variations in parameters such as $\mathrm{pH}$, adsorbent-adsorbate concentration, time and even ionic strength. Among the physicochemical treatment, process of adsorption is found to be highly effective, cheap and easy method and it has inspired the investigators to search for suitable low cost adsorbent. In recent years considerable attention has been devoted to the study of different types of low cost material such as some natural polymers like tamarind kernel powder, guar gum, chitin, chitosan etc.

Here in present paper, we are using the Power plant waste material fly ash for producing zeolites for the removal of Heavy metal ions.

\section{Experimental}

The main raw material, coal fly ash samples were collected from electrostatic precipitators of different thermal power plants of Rajasthan (India). The samples contained both amorphous (mainly $\mathrm{SiO}_{2}, \mathrm{Al}_{2} \mathrm{O}_{3}$ ) and crystalline components (mainly quartz and mullite). Table 1 presents the physicochemical properties of the fly ash samples used in the pre-sent investigation. As can be seen from this table, the fly ash samples used were of 'Class F' type with $\mathrm{SiO}_{2}, \mathrm{Al}_{2} \mathrm{O}_{3}$ and iron oxide as the major constituents. Commercial $13 \mathrm{X}$ zeolite was purchased from SRL Pvt. Ltd., Mumbai, India. Sodium hydroxide was procured from Glaxo Laboratories (India) Ltd.

Table 1. The proximate analysis report of the F-grade coal collected from thermal power plants of Rajasthan

\begin{tabular}{ccccccccc}
\hline Sample & SM\% & IM\% & TM\% & VM\% & ASH \% & FC\% & $\begin{array}{c}\text { GCV(ADB) } \\
\mathrm{kcal} / \mathrm{kg}\end{array}$ & $\begin{array}{c}\text { GCV(ARB) } \\
\mathrm{kcal} / \mathrm{kg}\end{array}$ \\
\hline $\mathrm{A}$ & 6.8 & 1.6 & 8.4 & 25.5 & 46.88 & 26.02 & 3548 & 3298 \\
$\mathrm{~B}$ & 7.2 & 1.5 & 8.7 & 24.1 & 45.6 & 28.8 & 3756 & 3412 \\
\hline
\end{tabular}

\section{Abbreviations}

$\mathrm{SM}=$ Surface Moisture,

$\mathrm{TM}=$ Total Moisture,

$\mathrm{IM}=$ Inherent Moisture,

$\mathrm{FC}=$ Fixed Carbon,

$\mathrm{VM}=$ Volatile Matter,

GCV $(\mathrm{ADB})=$ Gross calorific value (Air dry basis),

GCV $(\mathrm{ARB})=$ Gross calorific Value (As received basis)

Table 2. XRF analysis report of the fly ash which generated from the thermal power plants which uses the above f-grade coal

\begin{tabular}{clcc}
\hline & \multicolumn{3}{c}{ Fly Ash Quality Parameters in \% } \\
S. No. & Parameters & FA-1, \% & FA-2, \% \\
\hline 1 & $\mathrm{Na}_{2} \mathrm{O}$ & 2.21 & 1.88 \\
2 & $\mathrm{Al}_{2} \mathrm{O}_{3}$ & 30.12 & 28.69 \\
3 & $\mathrm{SiO}_{2}$ & 55.19 & 58.32 \\
4 & $\mathrm{~K}_{2} \mathrm{O}$ & 1.40 & 0.80 \\
5 & $\mathrm{CaO}$ & 0.76 & 0.60 \\
6 & $\mathrm{TiO}_{2}$ & 2.96 & 3.20 \\
7 & $\mathrm{Fe}_{2} \mathrm{O}_{3}$ & 4.62 & 4.42 \\
8 & $\mathrm{BaO}$ & 1.30 & 0.23 \\
9 & $\mathrm{MgO}$ & 1.93 & 2.10 \\
\hline
\end{tabular}




\section{Methods}

The physical and chemical characterization of the Raw materials \& zeolites was carried out using XRF, Oven, muffle furnace and Bomb calorimeter. Various water samples were analyzed by using $\mathrm{pH}$ meter, TDS meter \& spectrophotometer. Ojha ${ }^{4}$ reported the synthesis method for zeolite from Thermal power plant ash.

\section{Zeolite synthesis}

Before any treatment, the raw fly ash samples were first screened through a BSS Tyler sieve of 80 -mesh size to eliminate the larger particles. The unburnt carbon (4-6\%) along with other volatile materials present in fly ash was removed by calcinations at $800( \pm 10){ }^{\circ} \mathrm{C}$ for $2 \mathrm{~h}$. Fly ash samples were further treated with hydrochloric acid to increase their activity in zeolite formation. The acid treatment helped to dealuminate the fly ash and removed iron to a certain extent, thereby increasing the activity, thermal stability and acidity of the zeolite, all aiming for better catalytic applications.

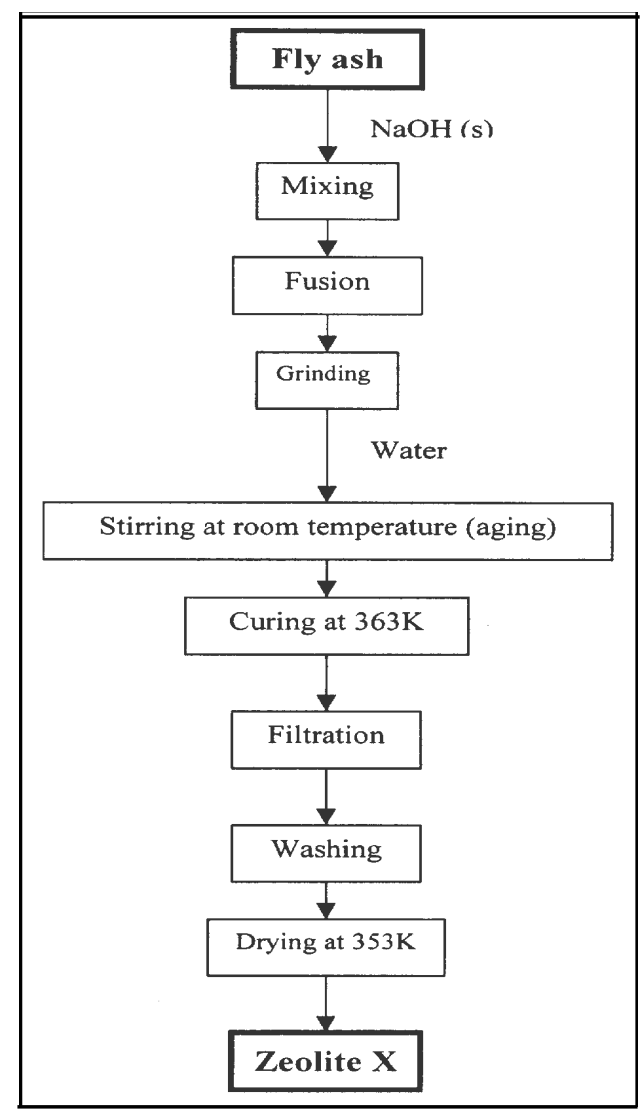

Figure 1. Process flow diagram for synthesis of zeolite from fly ash

Mixture of sodium hydroxide and fly ash (calcined and $\mathrm{HCl}$ treated) in a pre-determined ratio, was milled and fused in a stainless steel tray at different temperatures ranging from $500-650{ }^{\circ} \mathrm{C}$ for $1 \mathrm{~h}$. The sodium hydroxide to fly ash ratio (by weight) was varied from 1.0-1.5. The resultant fused mixture was then cooled to room temperature, ground further and added 
to water ( $10 \mathrm{~g}$ fly ash/100 $\mathrm{mL}$ water). The slurry thus obtained was agitated mechanically in a glass beaker for several hours. It was then kept at around $90{ }^{\circ} \mathrm{C}$ for $6 \mathrm{~h}$ without any disturbance. The flow diagram of the synthesis process is shown in Figure 1. The resultant precipitate was then repeatedly ashed with distilled water to remove excess sodium hydroxide, filtered and dried. The sodium hydroxide added to the fly ash not only works as an activator, but also adjusts the sodium content in the starting material. Mullite and $a$ - quartz present in the fly ash are the sources of aluminum and silicon, respectively, for zeolite Formation

\section{Results and Discussion}

From the XRF analysis it's found that the newly synthesized zeolites A \& B's physico chemical properties found almost similar to the commercial 13-X Zeolite which is shown in Table 3. The experimental results shows that the synthesized zeolites A \& B properties is quit resembles with the commercial zeolites.

Table 3. Physico chemical properties of commercial zeolite \& synthesized zeolite

\begin{tabular}{ccccc}
\hline \multicolumn{5}{c}{ Physico chemical properties of commercial zeolite \& synthesized zeolite in \% } \\
\hline S. No. & Parameters & $\mathrm{A}$ & $\mathrm{B}$ & Commercial 13X zeolite \\
\hline 1 & $\mathrm{Na}_{2} \mathrm{O}$ & 13.20 & 12.80 & 15.67 \\
2 & $\mathrm{Al}_{2} \mathrm{O}_{3}$ & 27.90 & 28.10 & 31.87 \\
3 & $\mathrm{SiO}_{2}$ & 50.78 & 49.33 & 48.26 \\
4 & $\mathrm{~K}_{2} \mathrm{O}$ & 0.55 & 0.68 & 0.07 \\
5 & $\mathrm{CaO}$ & 1.10 & 1.21 & 0.37 \\
6 & $\mathrm{TiO}_{2}$ & 2.40 & 1.90 & 0.08 \\
7 & $\mathrm{Fe}_{2} \mathrm{O}_{3}$ & 2.21 & 3.10 & 3.00 \\
8 & $\mathrm{BaO}$ & 0.70 & 0.78 & 0.00 \\
9 & $\mathrm{MgO}$ & 0.65 & 0.48 & 0.00 \\
\hline
\end{tabular}

\section{Removal of heavy metals from newly synthesized zeolite}

Zeolites adsorb a number of organic substances. This mineral has the largest affinity for polar organic components, for example chlorinated hydrocarbons. Depending on the diameter of the molecules, these are either adsorbed in the micro or mesopores ${ }^{7,8}$. The capacity of the adsorption is strongly dependent on the circumstances at which the adsorption is performed. At the moment, further investigations are still being performed in this field of interest.

The adsorption of heavy metals by zeolites is largely analogous to the removal of ammonia'. If there are a number of different cations present in the wastewater, the adsorption capacity per ion will be lower as a consequence of competition between the different cations. The adsorption will depend on relative selectivity of zeolites for the different ions, the composition of water and the temperature ${ }^{10}$. The relative selectivity is determined by the hydrated diameter, the charge and the mobility of the ions. This property enables zeolites to exchange harmful ions present in the water for harmless ions present in its structure.

We took samples of effluents of various metallurgical industries. These samples were treated with newly synthesized zeolite A \& B as described in Table 3. The results are reported in Table 4 and 5. 
Table 4. Characteristics of effluents contaminated with heavy metal ions obtained from various units of mineral and metal processing industries

\begin{tabular}{lcc}
\hline \multirow{2}{*}{ Characteristics } & \multicolumn{2}{c}{ Sources } \\
\cline { 2 - 3 } & $\begin{array}{c}\text { Effluent of metallurgical } \\
\text { industry X }\end{array}$ & $\begin{array}{c}\text { Processing plant } \\
\text { water of industry Y }\end{array}$ \\
\hline Colour & Reddish yellow & Dull white \\
$\mathrm{pH}$ & 9.0 & 8.0 \\
Total hardness, ppm & 655 & 845 \\
Metal ions, in ppm : & & \\
Iron & 124 & 1.65 \\
Copper & 0.76 & 0.60 \\
Zinc & 5.83 & 0.31 \\
Lead & 0.66 & 0.95 \\
Cadmium & 0.25 & 0.07 \\
Magnesium & 65 & 76 \\
Calcium & 174.4 & 292.4 \\
Anions, in ppm : & & \\
Cyanide & 0.05 & 0.023 \\
Fluoride & 0.44 & 0.55 \\
Sulphate & 713.01 & 952.02 \\
\hline
\end{tabular}

Table 5. Removal of toxic metal ions from the effluents from various mineral and metal processing industries. (The contact time for the reaction was $6 \mathrm{hrs}$ used for the below experiment)

\begin{tabular}{|c|c|c|c|c|}
\hline \multirow[b]{2}{*}{ Source } & \multicolumn{4}{|c|}{ Concentration of various metal ions, ppm } \\
\hline & Metal ions & $\begin{array}{l}\text { Untreated } \\
\text { effluents }\end{array}$ & $\begin{array}{l}\text { After treatment } \\
\text { with Zeolite-A }\end{array}$ & $\begin{array}{c}\text { After treatment } \\
\text { with Zeolite-B at } \\
\text { pH } 8.0\end{array}$ \\
\hline Effluent & Iron & 124 & 0.95 & 0.70 \\
\hline metallurgical & Copper & 0.76 & 0.02 & Nil \\
\hline industry $\mathrm{X}$ & Zinc & 5.83 & 0.31 & 0.08 \\
\hline $\mathrm{pH}=9.0$ & Lead & 0.66 & Nil & 0.01 \\
\hline Processing plant & Iron & 1.65 & Nil & Nil \\
\hline water of & Copper & 0.60 & 0.01 & Nil \\
\hline industry $\mathrm{Y}$ & Zinc & 0.31 & Nil & Nil \\
\hline $\mathrm{pH}=8.0$ & Lead & 0.95 & Nil & 0.01 \\
\hline
\end{tabular}

This study shows that the Zeolites A \& B which produced from the Thermal power plants fly ash samples FA-1 \& FA-2 respectively can be used for the removal of metals from aqueous solution with very good efficiency. Good removal efficiency particularly for Fe, $\mathrm{Cu}, \mathrm{Zn} \& \mathrm{~Pb}$ were observed.

\section{Conclusion}

Present study reveals that the synthesis of Zeolite from the fly ash is a new approach \& removal efficiency of the heavy metals mainly depends upon the $\mathrm{pH}$ of the medium \& contact time. 


\section{References}

1. Breck DW, Zeolite molecular sieves (New York: John Wiley and sons) 1974.

2. Davidovits $\mathrm{J}$ and Comrie $\mathrm{D}$, Division of Environmental Chemistry, American Chemical Society, Toronto, 1988, Extended Abstracts, 237-240.

3. Davidovits J, J Materials Education, 1994, 16(2-3), 91-137.

4. Keka Ojha, IIT Kharagpur, Bull Mater Sci (C) Indian Academy of Sciences, 2004, 27(6), 555-564.

5. Jaarsveld J G S V and Deventer J S J V, Ind Eng Chem Res., 1999, 38(10), 39323941.

6. $\quad \mathrm{Xu} \mathrm{H}$ and Deventer J S J V, Int J Mineral Processing, 2000, 59(3), 247-266.

7. Hui K S, Chao C Y H and Kot S C, J Hazard Mater., 2005, 127(1-3) 89-101

8. Erdem E, Karapinar N and Donat R, J Colloid Interf Sci., 2004, 280(2), 309-314

9. Wei Qiu and Ying Zheng, Chem Engg J., 2009, 145, 483-488.

10. Clair N Sawyer, Perry L McCarty and Gene F Parkin, Chemistry for Environ. Engg and Sci, New York McGraw Hill. ISBN 0-07-248066-1, 2003, $5^{\text {th }}$ Edition. 


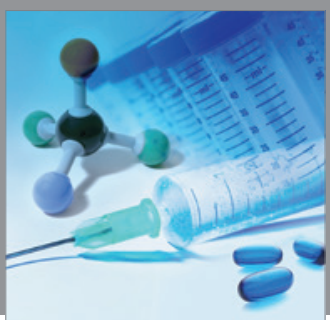

International Journal of

Medicinal Chemistry

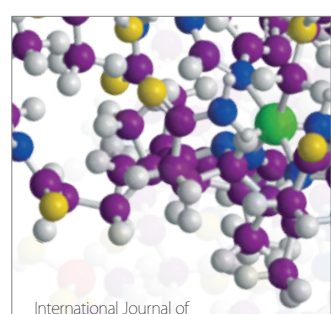

Carbohydrate Chemistry

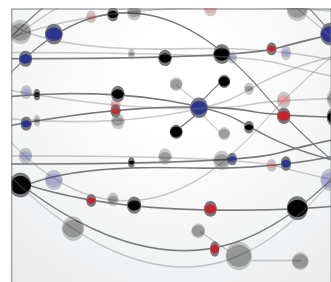

The Scientific World Journal
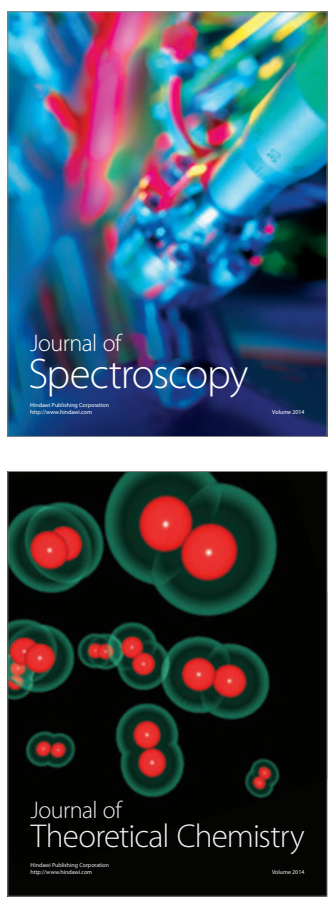
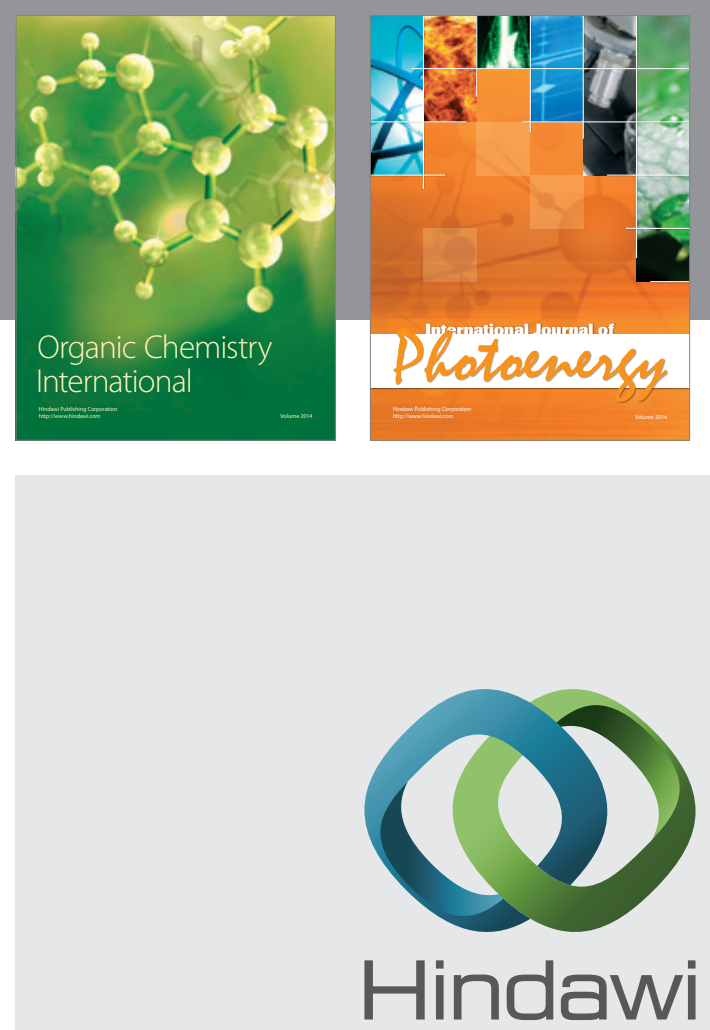

Submit your manuscripts at

http://www.hindawi.com
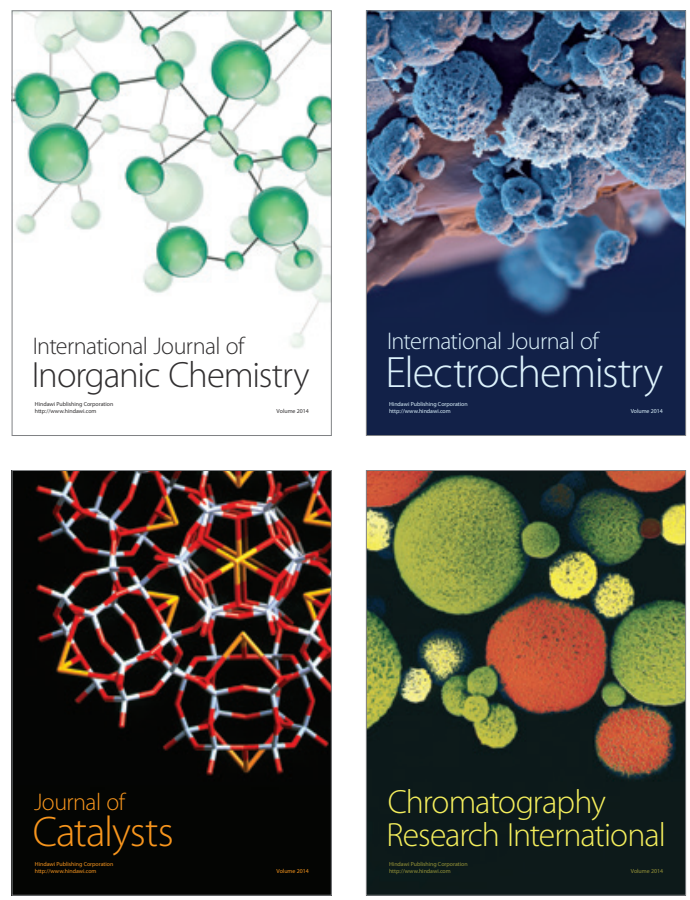
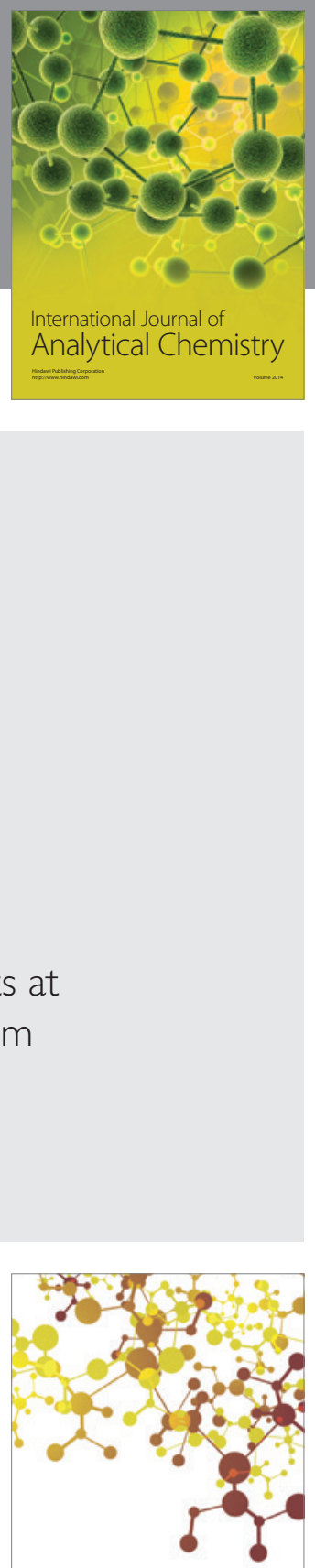

Journal of

Applied Chemistry
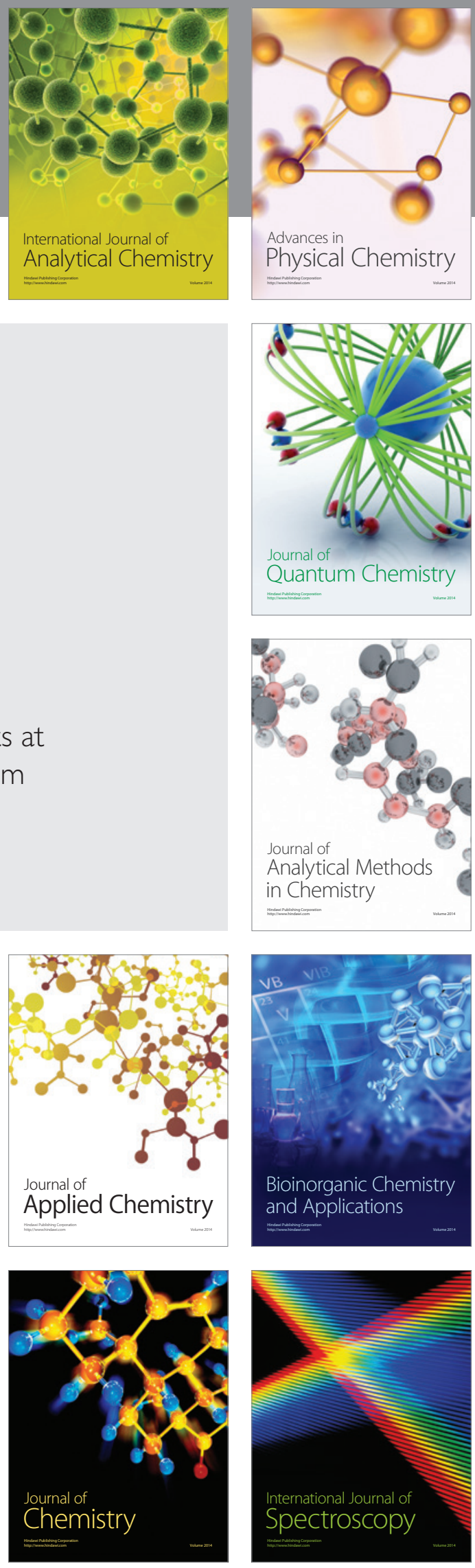